\title{
Effect of FYM, Mulching and Agro-Chemicals on Yield, Nutrient Content and their uptake by Wheat (Triticum aestivum L.) under Different Sowing Dates
}

\author{
Banshi Lal Bhateshwar ${ }^{1}$, S. K. Intodia ${ }^{1}$, Kamal Garg ${ }^{2 *}$, \\ Rajudevi Kantwa ${ }^{3}$ and Ramniwas ${ }^{4}$ \\ ${ }^{1}$ Department of Agronomy, MPUA\&T Udaipur, India \\ ${ }^{2}$ Division of Agronomy, IARI New Delhi, India \\ ${ }^{3}$ Department of Agronomy, SKNAU, Jobner, India \\ ${ }^{4}$ Department of Agronomy, SKRAU, Bikaner, India
}

*Corresponding author

\section{A B S T R A C T}

\section{Ke y w o r d s}

Agro-chemicals, FYM, Mulching, Nutrient content, Sowing date and Yield.

\section{Article Info}

Accepted:

05 April 2020

Available Online:

10 May 2020

\begin{abstract}
A field experiment was conducted at Instructional Farm, Rajasthan College of Agriculture, Udaipur during rabi 2016-17 to study the effect of FYM, mulching and agro-chemicals on yield, nutrient content and their uptake by wheat under different sowing dates. The experiment consisted of 12 treatment combinations comprising of two sowing dates (Timely, Late) and six management practices, viz., control, FYM, Mulching, FYM + Mulching, FYM + Mulching + $\mathrm{ZnSO}_{4}$ and FYM + Mulching $+\mathrm{KCl}\left(\mathrm{P}_{0}, \mathrm{P}_{1}, \mathrm{P}_{2}, \mathrm{P}_{3}, \mathrm{P}_{4}, \mathrm{P}_{5}\right)$. The experiment was conducted in factorial randomized block design and replicated thrice. Results showed that timely sowing of crop had significant effect on yield attributes (effective tillers, grains ear ${ }^{-1}$, ear length, grain weight ear ${ }^{-1}$ ), yield (grain, straw and biological) and nutrient uptake (N, P and K) over control. Maximum grain yield (5461 kg ha ${ }^{-1}$ ), straw yield $\left(6124 \mathrm{~kg} \mathrm{ha}^{-1}\right)$ and biological yield $\left(11585 \mathrm{~kg} \mathrm{ha}^{-1}\right)$ were recorded with timely sown crop, which was significantly higher over late sown crop. Result further showed that application of $10 \mathrm{t} \mathrm{ha}^{-}$ ${ }^{1} \mathrm{FYM}+4.0 \mathrm{t} \mathrm{ha}^{-1}$ Mulch $+0.2 \% \mathrm{KCl}\left(\mathrm{P}_{5}\right)$ recorded highest grain yield $\left(5400 \mathrm{~kg} \mathrm{ha}^{-1}\right)$, straw yield $\left(6633 \mathrm{~kg} \mathrm{ha}^{-1}\right)$ and biological yield $\left(12033 \mathrm{~kg} \mathrm{ha}^{-1}\right)$ followed by $10 \mathrm{tha}^{-1} \mathrm{FYM}+4.0 \mathrm{tha}^{-1}$ Mulch + $0.5 \% \mathrm{ZnSO}_{4}\left(\mathrm{P}_{4}\right)$ and $10 \mathrm{tha}^{-1} \mathrm{FYM}+4.0 \mathrm{tha}^{-1}$ Mulch $\left(\mathrm{P}_{3}\right)$. Also, same treatment resulted in higher nutrient content in grain and straw and their uptake.
\end{abstract}

\section{Introduction}

Wheat (Triticum aestivum L.) is one of the important food crops grown world-wide. It is the second most important cereal after rice in India a key crop of the green revolution and post green revolution era. It is the main staple food of nearly 35 per cent of the world population. It provides 21 per cent of the food calories and 20 per cent protein for more than 4.5 billion people in 94 developing countries (Braun et al., 2010). Further, with increased global population and change in consumption preference the demand of wheat increased substantial during the past 50 years. Globally wheat stands second in terms of total 
production with a quantum of 713.97 million tonnes from 220.45 million ha area (FAS/USDA, 2014). India has the largest area under wheat (31.2 million ha), with a productivity of $3075 \mathrm{~kg}$ ha-1 and is the second largest producer of wheat (95.9 million tonnes) after China in the world (FAOSTAT, 2017). In Rajasthan, the area and production of wheat was 3.3 million hectare and 12.43 million tonnes during 2016-17, respectively (Govt. of Rajasthan, 2016-17). The estimated food grain requirement of India by 2025 is around 300 million tonnes that has to be elevated from the current estimated production of 275 million tonnes (Government of India, 2016-17) and the share of wheat will be most important to meet the food grain requirement for future. Recent global climate change has made the situation more serious in agriculture-based enterprises. Climate change is impacting the natural ecosystems and is expected to have substantial adverse effects on productivity of various crops in India due to environmental stresses. In last few years, temperature fluctuation (variation) during wheat growing season was also observed in Rajasthan and thereby, growth and yield of timely as well as late sown wheat was adversely affected.

The impact of high temperature on wheat productivity can be minimized by adoption of various management practices. Selecting optimum planting time, avoids high temperature stress during anthesis and grain filling. High temperature at that time shortens the season and reduces yield. By adjusting sowing time crop can escapes to hot and desiccating wind during grain filling period. In addition, organic matter, residue retention, mulching, water management and foliar spray of $\mathrm{Zn}$ and $\mathrm{KCl}$ can also help in mitigating the temperature stress effects. Organic manure applications improve soil physical properties through increased soil aggregation, improves aggregate stability, decrease in the volume of microspores while increasing macrospores, increase saturated hydraulic conductivity and water infiltration rate and improves soil water-holding capacity at both field capacity and wilting point. Several workers reported positive effect of FYM on dry matter production, yield and nutrient uptake by wheat. Organic mulches provide better soil water status and improved plant canopy in terms of biomass, root growth, leaf area index and grain yield, which subsequently resulted in higher water and nitrogen uptake and their use efficiencies and may reduce expected reduction of economic yield under adverse climate during reproductive stage of wheat (Singh et al., 2011 and Chakraborty et al., 2010). In recent past some encouraging results were obtained with foliar spray of agro-chemicals and various nutrients at post flowering stage on yield of wheat. Potassium plays vital role under moisture stress condition by stimulating biological process in the plant cell such as enzymes activation, respiration, photosynthesis, chlorophyll synthesis, carbohydrate formation, water balance in leaves and regulation of stomata opening as well as direct effect on the disease resistance (Mesbah, 2009). Hence, the present experiment was conducted to assess the effect of FYM, mulching and agro-chemicals on yield, nutrient content and their uptake by wheat (Triticum aestivum L.) under different sowing dates.

\section{Materials and Methods}

The experiment was conducted during rabi season 2016-17 at Instructional Farm, Rajasthan College of Agriculture, Udaipur (Rajasthan). The soil of experimental site was clay loam in texture, having slight alkaline reaction ( $\mathrm{pH} 7.7)$. The soil was medium in available nitrogen $\left(295.3 \mathrm{~kg} \mathrm{ha}^{-1}\right)$ and phosphorus (18.4 $\left.\mathrm{kg} \mathrm{ha}^{-1}\right)$, and high in available potassium $\left(292.7 \mathrm{~kg} \mathrm{ha}^{-1}\right)$. The experiment comprised of twelve treatment 
combinations (two sowing dates and six management practices) that were laid out in factorial randomized block design and replicated three times. The plot size was 1.8 $\mathrm{m} \times 8.0 \mathrm{~m}$. The wheat variety HI-1544 was sown on 10 November, 2016 and 15 December, 2016 as per treatments. A uniform seed rate of $100 \mathrm{~kg} \mathrm{ha}^{-1}$ was used at inter row spacing of $20.0 \mathrm{~cm}$. In order to obtain uniform plant stand, seeds were weighed for each plot separately. Sowing was done manually in furrows followed by irrigation. Recommended dose of fertilizers, i.e., $90 \mathrm{~kg}$ $\mathrm{N}+60 \mathrm{~kg} \mathrm{P}_{2} \mathrm{O}_{5} \mathrm{ha}^{-1}$ were applied through DAP and urea. Half of $\mathrm{N}$ and full dose of $\mathrm{P}$ were applied as a basal dose at the time of sowing.

Remaining quantity of $\mathrm{N}$ were applied as top dressing on standing crop through urea in two equal split doses at the time of first and second irrigation. Well rotten FYM was applied @ $10.0 \mathrm{t} \mathrm{ha}^{-1}$ at the time of sowing as per treatments. Maize stover was applied as mulch@4.0 t ha ${ }^{-1}$ just after sowing of the crop as per treatments. Agro-chemicals $\left(\mathrm{ZnSO}_{4}\right.$ and $\left.\mathrm{KCl}\right)$ were weighed as per treatments and dissolved in water (600 liter $\mathrm{ha}^{-1}$ ) and applied as per treatments. The agrochemicals were sprayed through knapsack sprayer fitted with flat fan nozzle. Five plants were randomly selected from each plot. Number of effective tillers was manually counted on $1.0 \mathrm{~m}^{-1}$ row length at harvest. Effective tillers from four randomly selected $0.5 \mathrm{~m}$ area were counted in each plot and average number of effective tillers $1.0 \mathrm{~m}^{-1}$ was worked out. The randomly selected five ears were separately threshed and grains were counted for determining average number of grains ear ${ }^{-1}$. The randomly selected five ears were separately threshed and weighed. Then average grain weight ear $^{-1}$ was computed. The length of five randomly selected ears from each experimental plot was measured including awns and averaged.
It was expressed in $\mathrm{cm}$. A composite sample of sun-dried grains was taken from the final produce in each plot at the time of threshing. Thereafter, 1000 grains were counted, weighed and expressed in $\mathrm{g}$. The crop was harvested on maturity. The plants from border area were harvested separately and removed from each plot.

The plants from net area were harvested and produce was tied in bundles and tagged. Dried bundles of individual plot were weighed to record biological yield and then threshed with power operated thresher and the produce was winnowed, cleaned and weighed separately to record grain yield plot $^{-1}$ and to compute yield $\mathrm{kg} \mathrm{ha}^{-1}$. The harvest index was calculated by dividing the economic yield (grain yield) by biological yield and expressed in per cent (Singh and Stoskopf 1971).

$$
\text { Harvest index }(\%)=\frac{\text { Economic yield }}{\text { Biological yield }}
$$

Plant sample of the crop collected at harvesting stage were first oven dried and then processed for estimation of $\mathrm{N}, \mathrm{P}$ and $\mathrm{K}$. Estimation of $\mathrm{N}$ was done by colorimetric method using Nessler's' reagent to develop colour (Snell and Snell 1949). P content was determined by Vanadomolybdo phosphoric acid yellow colour method (Richards, 1954) while $\mathrm{K}$ by Flame photometer method (Jackson, 1973) method. The total uptake of nitrogen, phosphorus and potassium was computed from $\mathrm{N}, \mathrm{P}$ and $\mathrm{K}$ concentration in grain and straw at harvest stage using the following relationship:

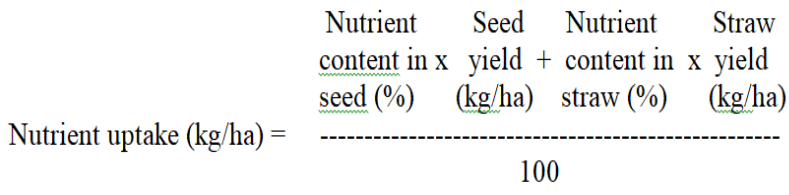




\section{Results and Discussion}

\section{Effect on yield}

\section{Sowing date}

The data presented in (Table 1 and 2) show that different dates of sowing brought about significant variation on yield attributes (effective tillers, grains ear ${ }^{-1}$, ear length, grain weight ear $^{-1}$ ) and yield (grain, straw and biological) over control. Timely sown crop sown recorded significantly higher yield attributes viz., effective tillers $\mathrm{m}^{-1}$ row length, grains ear ${ }^{-1}$, ear length, grain weight ear ${ }^{-1}$ and test weight over late sown crop (Table 1).

The interesting behavior exhibited by different sowing dates may be explained by the fact that early sown crop was exposed to favorable weather during complete life span and thus the different phases of plant life was completed at appropriate timings, which resulted in production of more number of effective tillers. The late sown crop could not enjoy advantages of favorable weather conditions available for the early sowing. Similar responses were also recorded by Kumar and Sharma (2003), Shirpurkar et al., (2008) and Mukherjee (2012).

The timely sown crop produced ears of maximum length. It might be attributed due to the fact that when the crop was sown late, there was low temperature in the beginning but after mid-February onward the temperature started rising very fast and the plant did not get sufficient favorable environment to express their full potentiality.

Similar observations were also reported by Kumar and Sharma (2003) and Pandey et al., (2010). Number of grains ear ${ }^{-1}$ significantly influenced by different sowing dates and decreased delayed sowing. It was influenced by environment particularly that of temperature prevailed during the time of sowing, vegetative and reproductive stages. In timely sown crop, the numbers of grains ear ${ }^{-1}$ were more and of good weight, which positively contributed to high yield. High temperature during the later part of reproductive stages in late sowing caused forced maturity resulting in development of grains which were small, shriveled and of low weight (Table 1).

Environment particularly that of temperature prevailed during the time of reproductive phase influenced the test weight. Significant influence of date of sowing was observed on test weight and was higher in timely sown crop and decreased as sowing was delayed.

This might be due to the fact that under later sown conditions the grains were forced to mature and dry because of sudden rise in temperature coupled with low relative humidity during milking to physiological maturity. Thus, the grains obtained from late sown crop, i.e., $15^{\text {th }}$ December were small and shriveled and ultimately resulted in lower test weight. The results are in close agreement with findings of Dhaka et al., (2006), Shirpurkar et al., (2008) and Mukherjee (2012) and Amrawat et al., (2014).

Maximum grain yield (5461 $\mathrm{kg} \mathrm{ha}^{-1}$ ), straw yield (6124 $\mathrm{kg} \mathrm{ha}^{-1}$ ) and biological yield (11585 $\mathrm{kg} \mathrm{ha}^{-1}$ ) were recorded with timely sown crop registered significant increase in grain $(22.96 \%)$, straw $(14.29 \%)$ and biological $(18.22 \%)$ yields (Table 1) over late sown crop. Late sown crop $\left(15^{\text {th }}\right.$ December) experienced higher mean temperature during reproductive phase as against the mean temperature in normal sown crop. This shortened the crop duration by 20 days compared to normal sown crop and caused force maturity, resulted in shriveled grain and ultimately low grain yield under late sown crop. 


\section{FYM, mulching and agro-chemicals}

A significant variation in yield attributes and yield of wheat was observed due to various management practices (FYM, mulch alone and in combination with agro-chemicals). FYM + mulch alone and in combination with foliar spray of $0.5 \% \mathrm{ZnSO} 4$ and $0.2 \% \mathrm{KCl}$ significantly improved yield attributing characters in wheat, viz., effective tillers $\mathrm{m}^{-1}$ row length, grains ear ${ }^{-1}$, ear length, grain weight ear $^{-1}$ and test weight over control. The highest value of yield attributing characters was recorded under treatment $10 \mathrm{t} \mathrm{ha}^{-1}$ FYM $+4.0 \mathrm{t} \mathrm{ha}^{-1}$ mulch $+0.2 \% \mathrm{KCl}$. The reason for better performance of $\mathrm{KCl}$ spray in combination with FYM + mulch was owing to the fact that $\mathrm{KCl}$ spray helped in maintaining higher water potential, as potassium plays important role in osmoregulation and thereby it increases osmotic potential of leaves, which causes reduction in loss of water from leaves. Foliar spray of potassium fertilizer increases the photosynthates production in plant and thus increases the translocation of dry matter to the grain, which ultimately increases the total grain weight and yield (Kajla et al., 2015).

Also, potassium plays vital role under moisture-stress condition by stimulating biological process in the plant cell such as enzymes activation, photosynthesis, chlorophyll synthesis, carbohydrate formation, water balance in leaves and stomata opening (Mesbah, 2009). Further, 10 $\mathrm{t} \mathrm{ha}^{-1} \mathrm{FYM}+4.0 \mathrm{t} \mathrm{ha}^{-1}$ mulch $+0.5 \% \mathrm{ZnSO}_{4}$ and $10 \mathrm{t} \mathrm{ha}^{-1} \mathrm{FYM}+4.0 \mathrm{t} \mathrm{ha}^{-1}$ mulch $+0.2 \%$ $\mathrm{KCl}$ also improved test weight of wheat grains (Table 1). Grain yield is a resultant of yield attributes and therefore, expression of yield attributes. Results revealed that application of $10 \mathrm{t} \mathrm{ha}^{-1} \mathrm{FYM}+4.0 \mathrm{t} \mathrm{ha}^{-1}$ Mulch $+0.2 \% \mathrm{KCl}\left(\mathrm{P}_{5}\right)$ recorded highest grain yield $\left(5400 \mathrm{~kg} \mathrm{ha}^{-1}\right)$, straw yield $(6633$ $\mathrm{kg} \mathrm{ha}^{-1}$ ) and biological yield (12033 kg ha-1) followed by $10 \mathrm{t} \mathrm{ha}^{-1} \mathrm{FYM}+4.0 \mathrm{t} \mathrm{ha}^{-1}$ Mulch $+0.5 \% \mathrm{ZnSO}_{4}\left(\mathrm{P}_{4}\right)$ and $10 \mathrm{t} \mathrm{ha}^{-1} \mathrm{FYM}+4.0 \mathrm{t}$ $\mathrm{ha}^{-1}$ Mulch $\left(\mathrm{P}_{3}\right)$. Application of $10 \mathrm{t} \mathrm{ha}^{-1} \mathrm{FYM}$ $+4.0 \mathrm{t} \mathrm{ha}^{-1}$ mulch, $10 \mathrm{t} \mathrm{ha}^{-1} \mathrm{FYM}+4.0 \mathrm{t} \mathrm{ha}^{-1}$ mulch $+0.5 \% \mathrm{ZnSO}_{4}$ and $10 \mathrm{t} \mathrm{ha}^{-1} \mathrm{FYM}+$ $4.0 \mathrm{t} \mathrm{ha}^{-1}$ mulch $+0.2 \% \mathrm{KCl}$ registered significant increase in grain yield by 11.05 , 12.30 and 18.68 per cent, respectively over control (4550 kg ha ${ }^{-1}$ ) (Table 1) over control. This could be ascribed due to overall improvement in crop growth as reflected by plant height, DMA, number of tillers $\mathrm{m}^{-1}$ row length and yield bearing characters. A significant increase in straw and biological yields was observed under various management practices (Table 1). This might be due to favorable effect of FYM, mulch, $\mathrm{FYM}+$ mulch and foliar application of $\mathrm{ZnSO}_{4}$ and $\mathrm{KCl}$ on growth and development of the crop. Regarding harvest index, no definite trend was observed with various management practices.

\section{Effect on nutrient content and uptake}

\section{Sowing date}

Nitrogen, phosphorus and potassium contents in grain and straw influenced significantly by different sowing dates. Nutrient uptake by grain and straw was also significantly affected by different sowing dates (Table 2). The higher nitrogen $(115.91 \mathrm{~kg} / \mathrm{ha})$, phosphorus (28 kg/ha) and potassium (105.06 kg/ha) uptake was recorded under timely sown crop. Significant increase in nitrogen, phosphorus and potassium uptake by grain as well as total uptake of wheat under timely sown crop recorded in the present study might be due to higher nitrogen, phosphorus and potassium content in grain and straw. The positive impact of nutrient uptake in grain seems to be due to better growth of crop, as evidenced by higher dry matter accumulation, which might have maintained adequate supply of metabolites for better growth. 
Table.1 Effect of FYM, mulching and agro-chemicals on yield attributes, yield and harvest index of wheat

\begin{tabular}{|c|c|c|c|c|c|c|c|c|c|}
\hline \multirow[t]{2}{*}{ Treatments } & \multicolumn{5}{|c|}{ Yield attributes } & \multicolumn{3}{|c|}{ Yield $\left(\mathrm{kg} \mathrm{ha}^{-1}\right)$} & \multirow{2}{*}{$\begin{array}{c}\text { Harvest } \\
\text { Index } \\
(\%)\end{array}$} \\
\hline & 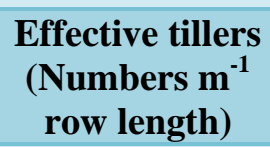 & $\begin{array}{c}\text { Grains } \\
\text { ear }^{-1}\end{array}$ & $\begin{array}{l}\text { Ear length } \\
\text { (cm) }\end{array}$ & $\begin{array}{l}\text { Grain weight } \\
\text { ear }^{-1} \text { (g) }\end{array}$ & $\begin{array}{c}\text { Test Weight } \\
\text { (g) }\end{array}$ & Grain & Straw & Biological & \\
\hline \multicolumn{10}{|l|}{ Sowing date } \\
\hline $\mathbf{D}_{1}$ & 95.24 & 49.11 & 13.67 & 2.52 & 49.56 & 5461 & 6124 & 11585 & 47.37 \\
\hline $\mathbf{D}_{2}$ & 81.39 & 45.11 & 12.44 & 2.10 & 40.15 & 4441 & 5358 & 9799 & 45.33 \\
\hline $\mathrm{SEm} \pm$ & 1.73 & 0.59 & 0.28 & 0.03 & 0.89 & 91 & 129 & 134 & 0.82 \\
\hline $\mathrm{CD}(\mathrm{P}=0.05)$ & 5.06 & 1.74 & 0.83 & 0.08 & 2.60 & 266 & 377 & 394 & NS \\
\hline \multicolumn{10}{|l|}{$\begin{array}{l}\text { FYM, mulching } \\
\quad \text { and } \\
\text { agro-chemicals }\end{array}$} \\
\hline $\mathbf{P}_{0}$ & 77.80 & 43.50 & 11.83 & 2.13 & 41.54 & 4550 & 4839 & 9389 & 48.32 \\
\hline $\mathbf{P}_{1}$ & 84.92 & 45.83 & 12.33 & 2.15 & 43.87 & 4783 & 5592 & 10375 & 46.01 \\
\hline $\mathbf{P}_{2}$ & 86.49 & 46.33 & 12.83 & 2.25 & 43.52 & 4808 & 5717 & 10525 & 45.80 \\
\hline $\mathbf{P}_{\mathbf{3}}$ & 93.23 & 46.67 & 13.33 & 2.28 & 45.09 & 5053 & 5652 & 10705 & 47.51 \\
\hline $\mathbf{P}_{4}$ & 93.60 & 48.67 & 13.50 & 2.43 & 46.05 & 5110 & 6015 & 11125 & 45.86 \\
\hline $\mathbf{P}_{5}$ & 93.87 & 51.67 & 14.50 & 2.60 & 49.05 & 5400 & 6633 & 12033 & 44.61 \\
\hline SEm \pm & 2.99 & 1.03 & 0.49 & 0.05 & 1.53 & 157 & 223 & 232 & 1.42 \\
\hline $\mathrm{CD}(\mathrm{P}=0.05)$ & 8.77 & 3.01 & 1.44 & 0.14 & 4.50 & 460 & 653 & 682 & NS \\
\hline
\end{tabular}

Note- NS- Non-significant, $\mathrm{D}_{1}$ - Timely sowing $\left(10^{\text {th }}\right.$ November, 2016), $\mathrm{D}_{2^{-}}$Late sowing $\left(15^{\text {th }}\right.$ December, 2016), $\mathrm{P}_{0^{-}}$Control, $\mathrm{P}_{1^{-}}-10 \mathrm{tha} \mathrm{C}^{-1} \mathrm{FYM}, \mathrm{P}_{2^{-}}-4 \mathrm{t}$ ha ${ }^{-1}$ Mulch, $\mathrm{P}_{3^{-}}$ $10 \mathrm{t} \mathrm{ha}^{-1} \mathrm{FYM}+4.0 \mathrm{t} \mathrm{ha}^{-1}$ Mulch, $\mathrm{P}_{4^{-}} 10 \mathrm{tha}^{-1} \mathrm{FYM}+4.0 \mathrm{tha}^{-1} \mathrm{Mulch}+0.5 \% \mathrm{ZnSO}_{4}, \mathrm{P}_{5^{-}} 10 \mathrm{t} \mathrm{ha}^{-1} \mathrm{FYM}+4.0 \mathrm{t} \mathrm{ha}^{-1} \mathrm{Mulch}+0.2 \% \mathrm{KCl}$. 
Table.2 Effect of FYM, mulching and agro-chemicals on nutrient content in grain and straw and their uptake by wheat

\begin{tabular}{|c|c|c|c|c|c|c|c|c|c|}
\hline \multirow[t]{2}{*}{ Treatments } & \multicolumn{2}{|c|}{$\begin{array}{c}\text { N concentration } \\
(\%)\end{array}$} & \multirow[t]{2}{*}{$\begin{array}{c}\text { Total N uptake } \\
\text { (kg/ha) }\end{array}$} & \multicolumn{2}{|c|}{$\begin{array}{c}\text { P concentration } \\
(\%)\end{array}$} & \multirow[t]{2}{*}{$\begin{array}{l}\text { Total P uptake } \\
\text { (kg/ha) }\end{array}$} & \multicolumn{2}{|c|}{$\begin{array}{c}\text { K concentration } \\
(\%)\end{array}$} & \multirow[t]{2}{*}{$\begin{array}{l}\text { Total K uptake } \\
\quad \text { (kg/ha) }\end{array}$} \\
\hline & Grain & Straw & & Grain & Straw & & Grain & Straw & \\
\hline \multicolumn{10}{|l|}{ Sowing date } \\
\hline $\mathbf{D}_{1}$ & 1.687 & 0.385 & 115.91 & 0.371 & 0.124 & 28.00 & 0.463 & 1.299 & 105.06 \\
\hline $\mathrm{SEm} \pm$ & 0.016 & 0.004 & 1.46 & 0.003 & 0.002 & 0.39 & 0.003 & 0.012 & 1.65 \\
\hline $\mathrm{CD}(\mathrm{P}=0.05)$ & 0.046 & 0.013 & 4.28 & 0.010 & 0.005 & 1.15 & 0.008 & 0.035 & 4.83 \\
\hline \multicolumn{10}{|c|}{$\begin{array}{l}\text { FYM, mulching and } \\
\text { agro-chemicals }\end{array}$} \\
\hline $\mathbf{P}_{2}$ & 1.567 & 0.364 & 96.72 & 0.346 & 0.118 & 23.46 & 0.454 & 1.250 & 93.70 \\
\hline $\mathbf{P}_{\mathbf{3}}$ & 1.592 & 0.373 & 102.07 & 0.352 & 0.122 & 24.89 & 0.463 & 1.286 & 96.34 \\
\hline $\mathbf{P}_{4}$ & 1.635 & 0.389 & 107.32 & 0.367 & 0.125 & 26.43 & 0.464 & 1.299 & 101.58 \\
\hline $\mathbf{P}_{5}$ & 1.648 & 0.393 & 115.81 & 0.376 & 0.128 & 29.06 & 0.489 & 1.379 & 118.04 \\
\hline SEm \pm & 0.027 & 0.008 & 2.53 & 0.006 & 0.003 & 0.68 & 0.005 & 0.021 & 2.86 \\
\hline $\mathrm{CD}(\mathrm{P}=\mathbf{0 . 0 5})$ & 0.080 & 0.022 & 7.41 & 0.017 & 0.008 & 1.98 & 0.014 & 0.061 & 8.37 \\
\hline
\end{tabular}

Note- $\mathrm{D}_{1^{-}}$- Timely sowing $\left(10^{\text {th }}\right.$ November, 2016), $\mathrm{D}_{2^{-}}$Late sowing $\left(15^{\text {th }}\right.$ December, 2016), $\mathrm{P}_{0^{-}}$Control, $\mathrm{P}_{1^{-1}} 10 \mathrm{t}_{\text {ha }}{ }^{-1} \mathrm{FYM}, \mathrm{P}_{2^{-}} 4 \mathrm{t}$ ha ${ }^{-1}$ Mulch, $\mathrm{P}_{3^{-}} 10 \quad \mathrm{t}$ ha ${ }^{-1}$ $\mathrm{FYM}+4.0 \mathrm{t} \mathrm{ha}^{-1}$ Mulch, $\mathrm{P}_{4^{-}} 10 \mathrm{tha}^{-1} \mathrm{FYM}+4.0 \mathrm{tha}^{-1}$ Mulch $+0.5 \% \mathrm{ZnSO}_{4}, \mathrm{P}_{5^{-}} 10 \mathrm{tha} \mathrm{h}^{-1} \mathrm{FYM}+4.0 \mathrm{t} \mathrm{ha}^{-1} \mathrm{Mulch}+0.2 \% \mathrm{KCl}$. 
Thus, better developed root system might have facilitated in more extraction of nutrients from soil and translocation to plant parts. Higher concentration of nutrients in grain along with grain and straw yields under timely sown crop resulted in higher nutrients. The results are in close agreement with those of Chourasiya et al., (2013) and Rahman et al., (2013).

\section{FYM, mulching and agro-chemicals}

Nitrogen, phosphorus and potassium contents in grain and straw influenced significantly by application of $10 \mathrm{t} \mathrm{ha}^{-1} \mathrm{FYM}+4.0 \mathrm{t} \mathrm{ha}^{-1}$ mulch $+0.5 \% \mathrm{ZnSO}_{4}$ and $10 \mathrm{t} \mathrm{ha}^{-1} \mathrm{FYM}+$ $4.0 \mathrm{t} \mathrm{ha}^{-1}$ mulch $+0.2 \% \mathrm{KCl}$. Further, phosphorus and potassium contents in grain increased by application of $10 \mathrm{t} \mathrm{ha}^{-1}$ FYM, 4.0 $\mathrm{t} \mathrm{ha}^{-1}$ mulch and $10 \mathrm{t} \mathrm{ha}^{-1} \mathrm{FYM}+4.0 \mathrm{t} \mathrm{ha}^{-1}$ mulch. Nutrient uptake by grain, straw and total was also significantly affected by application of $10 \mathrm{t} \mathrm{ha}^{-1} \mathrm{FYM}+4.0 \mathrm{t} \mathrm{ha}^{-1}$ mulch, $10 \mathrm{t} \mathrm{ha}^{-1} \mathrm{FYM}+4.0 \mathrm{t} \mathrm{ha}^{-1}$ mulch +0.5 $\% \mathrm{ZnSO}_{4}$ and $10 \mathrm{t} \mathrm{ha}^{-1} \mathrm{FYM}+4.0 \mathrm{t} \mathrm{ha}^{-1}$ mulch $+0.2 \% \mathrm{KCl}$ (Table 2).

Further, total uptake of nitrogen, phosphorus and potassium was significantly affected by application of $10 \mathrm{t} \mathrm{ha}^{-1} \mathrm{FYM}$ and $4.0 \mathrm{t} \mathrm{ha}^{-1}$ mulch. Significant increase in nitrogen, phosphorus and potassium uptake by grain and straw as well as total uptake of wheat under treatments $10 \mathrm{t} \mathrm{ha}^{-1} \mathrm{FYM}+4.0 \mathrm{t} \mathrm{ha}^{-1}$ mulch, $10 \mathrm{t} \mathrm{ha}^{-1} \mathrm{FYM}+4.0 \mathrm{t} \mathrm{ha}^{-1}$ mulch +0.5 $\% \mathrm{ZnSO}_{4}$ and $10 \mathrm{t} \mathrm{ha}^{-1} \mathrm{FYM}+4.0 \mathrm{t} \mathrm{ha}^{-1}$ mulch $+0.2 \% \mathrm{KCl}$ recorded in the present study might be due to higher nitrogen, phosphorus and potassium contents in grain and straw and as well as more production of biological yield. It is well established that nutrient uptake by the crop is primarily governed by dry matter accumulation and secondly on nutrient concentration at cellular level. Thus, enhanced uptake of nitrogen, phosphorus and potassium in grain, straw and total uptake by the crop under the influence of various management practices seems to be in accordance with overall improvement in growth, productivity and increase in nutrient concentration in plants.

On the basis of the findings of the present investigation, it can be concluded that under prevailing climatic condition of agro-climatic zone IV A of the Rajasthan timely sown wheat crop and application of treatment $10 \mathrm{t}$ $\mathrm{ha}^{-1} \mathrm{FYM}+4.0 \mathrm{t} \mathrm{ha}^{-1}$ mulch $+0.2 \% \mathrm{KCl}$ was found the most superior treatment combination for obtaining higher yield, nutrient content and their uptake by wheat over rest of the treatment.

\section{Acknowledgements}

The authors are thankful to Head, Department of Agronomy, Rajasthan College of Agriculture, MPUA\&T Udaipur for providing field staff, facilities and assistance in conducting this research.

\section{References}

Amrawat, Taruna., Solanki, N.S., Sharma, S.K. and Sumeriya, H.K. 2014. Analysis of wheat (Triticum aestivum L.) cultivars under different sowing dates and nitrogen levels. Annal of Biology 30(2): 253256.

Braun, H.J., Atlin, G. and Payne, T. 2010. Multi location testing as a tool to identify plant response to global climatic change. In: Climate Change and Crop Production (ed. C.R.P. Reynolds) CABI, London, U.K.

Chakraborty, D., Garg, R.N. and Tomar, R.K. 2010. Synthetic and organic mulching and nitrogen effect on winter wheat (Triticum aestivum L.) in a semi-arid environment. Agricultural Water Management 97(7): 738-748.

Chourasiya, A., Tomar, S.S., Tomar, S.P.S. and Srivastava, S.C. 2013. Response of wheat

(Triticum aestivum L.) varieties to sowing dates in Grid Region of Madhya Pradesh. Current Advances in 
Agricultural Sciences. 5(1): 129-131.

Dhaka, A.K., Bangarwa, A.S., Pannu, R.K., Malik, R.K. and Garg, R. 2006 Phenological development, yield and yield attributes of different wheat genotype as influenced by sowing time and irrigation levels. Agricultural Science Digest 26(3): 174-177.

FAOSTAT. 2017. FAO Statistical Year book World Food and Agriculture. http://www.fao.org/economic/ess/esspu blications/essyearbook/en/\#.U68A8v m SziU/

FAS/USDA. 2014. Foreign Agricultural Service/United States Department of Agriculture. Production, Supply and Distribution Online. http://apps.fas.usda. gov/psdonline/psdHome. aspx.

Govt. of India. 2016-17. State of Indian Agriculture. Directorate of Economics \& Statistics, Govt. of India pp- 9.

Govt. of Rajasthan. 2016-17. Rajasthan Agricultural Statistics at a Glance. Directorate of Agriculture, Rajasthan, Jaipur pp- 60.

Jackson, M. L. 1973 Soil Chemical Analysis, Prentice Hall, Pvt. Ltd. New Delhi, pp. 239- 241.

Kajla, M., Yadav, V.K., Chhokar, R.S. and Sharma, R.K. 2015. Management practices to mitigate the impact of high temperature on wheat. Journal of Wheat Research 7(1):1- 12 .

Kumar, R. And Sharma, S.N. 2003. Effect of levels of nitrogen on wheat as influenced by date of sowing. Annals of Agricultural Research 24: 104-110.

Mesbah, E. A. E. 2009. Effect of irrigation regimes and foliar spraying of potassium on yield, yield components and water use efficiency of wheat in sandy soils. World Journal Agricultural science 5(6): 662669.

Mukherjee, D. 2012. Effect of different sowing dates on growth and yield of wheat cultivars under mid hill situation of West Bengal. Indian Journal of Agronomy 57 (2):152-156.

Pandey, I.B., Dwivedi, D.K. and Pandey, R.K. 2009. Integrated nutrient management for sustaining wheat (Triticum aestivum) production under late sown condition. Indian Journal of Agronomy, 54: 306309.

Rahman, M.A., Chikushi, J., Saifizzaman, M., and Lauren, J.G. 2005. Rice straw mulching and nitrogen response of no-till wheat following rice in Bangladesh. Field Crops Research 01: 10.1016.

Richards, L.A. 1954. Diagnosis and improvement of saline and alkaline soils, USDA Hand book No. 60, Oxford and IBH Pub. Co., New Delhi.

Singh, I. D. and Stoskopf, N. C. 1971. Harvest index in cereals. Agronomy Journal 63(2): 224-226.

Singh, D., Singh, J.S., Kang and Aggarwal, N. 2011. Management practices to mitigate the impact of high temperature on wheat: A review Institute of Integrative Omics and Applied Biotechnology Journal 2 (7):11-22.

Shirpukar, G.N., Wagh, M.P. and Patil, D.T. 2008. Comparative performance of wheat genotype under different sowing dates. Agriculture Science of Digana 28:231-232.

Snell, P. D. and Snell, G. T. 1949. Colorimetric methods of analysis, 3rd Edn. Vol.II D. Van Nostrand Co. Inc., New York.

\section{How to cite this article:}

Banshi Lal Bhateshwar, S. K. Intodia, Kamal Garg, Rajudevi Kantwa, Ramniwas. 2020. Effect of FYM, Mulching and Agro-Chemicals on Yield, Nutrient Content and their uptake by Wheat (Triticum aestivum L.) under Different Sowing Dates. Int.J.Curr.Microbiol.App.Sci. 9(05): 787-795. doi: https://doi.org/10.20546/ijcmas.2020.905.087 